\title{
A Prospective Randomized Study Comparing Nifedipine versus Ritodrine for the Suppression of Preterm Labour
}

\author{
Fawzia Al-Qattan Alexander E. Omu Najwa Labeeb \\ Departments of Obstetrics and Gynaecology, Faculty of Medicine, Kuwait University and \\ Maternity Hospital, Kuwait
}

\author{
Key Words \\ Comparison $\cdot$ Nifedipine $\cdot$ Ritodrine $\cdot$ Preterm \\ contractions, inhibition
}

\begin{abstract}
Nifedipine is a dihydropyridine and a calcium channel blocker during the second phase of the action potential of uterine smooth muscle cells, and ritodrine is a $\beta$-sympathomimetic. Objective of Study: To compare the efficacy and side-effects of oral nifedipine to ritodrine in the inhibition of preterm labour. Methodology: Sixty parturients admitted to the Maternity Hospital with preterm labour who fulfilled the inclusion criteria were randomized into two equal therapy groups: (a) oral nifedipine $(n=30)$ and (b) intravenous ritodrine ( $n=30$ ). During the period, the parturients were under continuous monitoring of fetal well-being, maternal uterine contractions, blood pressure, and pulse and respiratory
\end{abstract}

rates. Both groups were given dexamethasone and followed up through delivery and the early neonatal period. Results: The incidence of preterm deliveries during the study period was $6.5 \%$. Ritodrine had a quicker onset of inhibition of uterine contractions, especially between 20 and 40 min after initiation of tocolytic therapy ( $p<0.04$ ). Labour was delayed on the average for $40 \mathrm{~h}$ in the nifedipine group compared to $24 \mathrm{~h}$ in the ritodrine group ( $p<0.05$ ). Eighteen patients $(60 \%)$ in the nifedipine group had cessation for more than $48 \mathrm{~h}$ compared to $7(30.4 \%)$ in the ritodrine group ( $p<0.05)$. Nifedipine inhibited uterine contractions for more than 7 days in more patients than ritodrine (13 versus $5, p<0.05)$. Ten patients in the nifedipine group went beyond 36 weeks of gestation compared to 4 in the ritodrine group ( $p<$ 0.03). In 5 (17.9\%) of the ritodrine group compared to none in the nifedipine group, treatment was abandoned because of severe

\begin{tabular}{ll}
\hline KARGER & (1) 1998 S. Karger AG, Basel \\
Fax +4161306 1234 $34-7571 / 00 / 0093-0164 \$ 17.50 / 0$ \\
$\begin{array}{l}\text { E-Mail karger@karger.ch } \\
\text { www.karger.com }\end{array}$ & $\begin{array}{l}\text { Accessible online at: } \\
\text { www.karger.com/journals/mpp }\end{array}$
\end{tabular}

Dr. Fawzia Al-Qattan

Department of Obstetrics and Gynaecology

Faculty of Medicine, Kuwait University

PO Box 24923, 13110 Safat (Kuwait)

Tel. +965 531 9601, Fax +965 5338906 
side-effects of nausea (11 versus $2, p<0.01$ ) and palpitations (16 versus $3, p<0.004$ ). There were no significant differences in the Apgar scores and neonatal morbidity. More infants in the ritodrine group $(17,73.9 \%)$ than in the nifedipine group $(14,46.1 \%, p<0.05)$ were admitted to the neonatal unit. Conclusion: Nifedipine is recommended for aborting preterm contractions because it has fewer side-effects, superior efficacy and greater ease of administration than intravenous ritodrine.

Copyright $\odot 2001$ S. Karger AG, Basel

\section{Introduction}

Preterm delivery is a common obstetric problem in which delivery takes place between 24 weeks and before 37 completed weeks of gestation. The rate of preterm deliveries varies from country to country and from institution to institution, but lies between 5 and $10 \%$ of all births in the UK [1], 8-10\% in the US [2], 6.7\% in continental Europe [3] and about 5.1\% in Saudi Arabia [4]. Preterm labour accounts for a disproportionate percentage of perinatal deaths. Although the incidence of preterm delivery is between 5 and $10 \%$ of pregnancies, it accounts for about $75 \%$ of the mortality and morbidity among newborns without congenital anomalies [5]. The aetiology of preterm labour is poorly understood. Sociobiological variables associated with preterm delivery include small stature, low maternal weight, age and poor socioeconomic status. Much stronger risk factors include previous abortions and previous preterm labour, and genital and urinary tract infection [1]. Prematurity and low birth weight related to preterm delivery are a major cause of neonatal mortality, morbidity and chronic health problems. Infants that survive preterm delivery are more likely to have de- velopmental delay, visual and hearing impairments, neurological problems or lung disease than term infants [6].

Population studies for the prevention of preterm delivery have had limited success because the aetiology is multifactorial: multiple pregnancy, ascending infection, pathology of the placenta and fetus, which may act in combination. In a 16-year study by Papiernik [7] in France, the effectiveness of a national policy for improving perinatal outcome by preventing preterm deliveries was demonstrated. However, as soon as the policy was no longer followed, recurrence rates of preterm deliveries increased again. Prevention of certain individuals at high risk and therapy is targeted at this group [5]. Strategies for reducing attendant perinatal mortality have therefore focused on the prevention of preterm delivery by inhibition of preterm labour with many agents. However, in many cases of preterm labour, tocolysis is not suitable, with only about 5\% being appropriate. A recent review by Tucker et al. [8] emphasized the difficulties of selecting appropriate patients with preterm labour for tocolysis. Of 13,119 singleton births between 1982 and 1986 in a US city, only 147 (5\%) were suitable for tocolysis out of 815 infants below 35 weeks, which is about $1 \%$ of the total births.

The most commonly used agents for tocolysis are $\beta$-adrenergic drugs, particularly ritodrine. The results of meta-analysis indicate that $\beta$-sympathomimetics can be expected to prolong pregnancy by only 24-48 $\mathrm{h}$ from the start of treatment [9]. This period is however useful for transfer of the parturient to a suitable centre with a tertiary neonatal unit and the administration of steroids. Secondly, the high incidence of undesirable serious sideeffects is of grave concern [10]. This limited value of ritodrine has necessitated the search and evaluation of newer tocolytic agents such as indomethacin and magnesium sulphate. 
The former has serious maternal, fetal and neonatal side-effects: peptic ulceration, gastro-intestinal bleeding, thrombocytopenia and allergic reactions. Fetal-pulmonary hypertension due to premature closure of the ductus arteriosus, necrotizing enterocolitis and intraventricular haemorrhage are other serious complications. In comparison with intravenous ritodrine, indomethacin delays labour by $24-48 \mathrm{~h}$ [11]. Prospective randomized clinical trials support the use of magnesium sulphate as a tocolytic agent rather than ritodrine or indomethacin because it carries fewer adverse fetal and maternal side-effects [12]. The use of magnesium sulphate for tocolysis, however, requires monitoring of blood levels. Moreover, magnesium sulphate is associated with a greater recurrence of preterm labour, an indication for further tocolysis [13].

Calcium channel blockers have been shown to have a relaxing effect on the myometrium. The commonly used agent of this class of tocolytic agents is nifedipine. It is a dehydropyridine calcium-entry blocker, with an effective uterine relaxant effect by inhibition of slow inward current of $\mathrm{Ca}^{++}$ions during the second phase of the action potential of uterine smooth muscle cells. Since the first report of the efficacy of nifedipine in the prevention of preterm labour by Ulmsten et al. [14] in 1980, and the confirmation by Read and Wellby [15] in 1986, nifedipine has been studied in a series of clinical trials, comparing it with ritodrine [16-20]. In spite of its few side-effects and attraction of administration by the oral route, the use of nifedipine in the inhibition of preterm labour is not generally common in Kuwait and other Middle Eastern countries.

The main objective of this study is to compare the efficacy and side-effects of oral nifedipine with ritodrine in a prospective randomized study.

\section{Materials and Methods}

Between August 1995 and April 1998, 60 patients out of 108 with preterm labour that occurred between 24 and 34 completed weeks of gestation without known medical or obstetric complication were enrolled prospectively in the study. The early cut-off of preterm labour was in accordance with the hospital policy following the British definition. Women were randomly selected using the random table to receive either oral nifedipine or intravenous ritodrine. For the purpose of this study, preterm labour was defined as regular uterine contractions at a frequency of 2-3 per 10-min interval with a documented change in cervical dilation or effacement before 34 completed weeks of gestational age. Between 34 and before 37 completed weeks of gestation, adequate fetal pulmonary maturity was expected. Therefore, such cases were excluded. Women were excluded from the study if they had cardiac disease, abruptio placentae, hyperthyroidism, severe pre-eclampsia, eclampsia, clinical signs of infection like fever and vaginal discharge or white cell count of more than $15,000 / \mathrm{cm}^{3}$ and positive high vaginal swab cultures. Any medical condition that would contra-indicate tocolytic therapy was excluded: polyhydramnios, a cervix with a dilation of $4 \mathrm{~cm}$ or greater, any fetal pathology, breech presentation, premature rupture of fetal membranes, intra-uterine fetal death, fetal distress or congenital malformation. All the women carried singleton pregnancies. Gestational age was calculated from the mother's last menstrual period and confirmed by ultrasonography at 16-22 weeks of gestation.

On admission, a detailed clinical evaluation was carried out. This included history of preterm labour, contraction onset, frequency, strength and duration; and passage of show, vaginal bleeding or draining of liquor. Physical examination included vital signs of pulse, temperature, respiratory rate and blood pressure. Abdominal examination was carried out to determine the fetal lie and presentation. Speculum examination was used to evaluate the cervical state and presence of preterm premature rupture of membranes and high vaginal swab for culture and antibiotic sensitivity tests. Routine cardiotocography was done to confirm uterine contractions and fetal well-being. Routine investigations included complete blood count, urine (routine, microscopy, culture and sensitivity), to exclude anaemia and infection. Ultrasound scan was done for all the patients in the labour room if it had not been done earlier, to confirm a singleton gestation and age and exclude placenta praevia and congenital anomalies. Both groups had continuous monitoring of 
fetal heart rate and uterine activity. Blood pressure, pulse and respiratory rates were measured every $15 \mathrm{~min}$ during the first $3 \mathrm{~h}$ of therapy. This was continued if contractions had not been aborted. Thereafter, monitoring was carried out hourly.

Initially, an intravenous infusion of 5\% dextrosesaline was administered. Nifedipine tocolysis was initiated with $30 \mathrm{mg}$ oral loading dose. If uterine contractions persisted after $2 \mathrm{~h}$, a second dose of $20 \mathrm{mg}$ was given. However, if labour was suppressed after the first or second dose, a maintenance dose of $20 \mathrm{mg}$ was given orally every $6 \mathrm{~h}$. The treatment in the ritodrine group was started with an intravenous infusion rate at $50 \mu \mathrm{g} /$ min. If the uterine contractions were aborted, oral therapy with $10 \mathrm{mg}$ every $4-6 \mathrm{~h}$ was started $1 \mathrm{~h}$ before discontinuation of intravenous ritodrine. In both study groups, fluid intake was limited to $2,400 \mathrm{ml} / 24 \mathrm{~h}$. Dexamethasone therapy of $12 \mathrm{mg}$ every $12 \mathrm{~h}$ for $24 \mathrm{~h}$ (i.e. 2 doses) was given to both groups for accelerated lung maturation. Expected outcome variables including the outcome of tocolysis in terms of timeframe of initiation of therapy to uterine quiescence and initiation of therapy to delivery, side-effects of tocolysis and perinatal outcome, Apgar scores, birth weight, occurrence of respiratory distress syndrome (RDS) and intraventricular haemorrhage and admission to a special care baby unit (SCBU). Mild RDS was defined as clinical signs of RDS, but not severe enough to require ventilation. In moderate RDS there are signs of RDS requiring ventilation and one dose of surfactant, while in severe RDS, two or more doses of surfactant are administered to the neonate. Tocolysis was considered to be successful if delivery was delayed for $48 \mathrm{~h}$. Treatment failure was said to exist if despite maximal dosages of nifedipine or ritodrine, uterine quiescence could not be achieved and delivery occurred. If a patient had a significant maternal side-effect, the medication was discontinued. Efficacy of these drugs in postponing delivery for 7 days or more was evaluated. Information concerning side-effects was carefully recorded on each patient. After discharge, they continued medication until 34 weeks of gestation and followed up to delivery with documentation of obstetric and neonatal outcome. Information about all preterm labour and preterm deliveries that occurred during the period of the study was collected from the labour ward delivery registers for the purpose of calculation of incidence of preterm deliveries in the hospital.

\section{Statistical Analysis}

These sample sizes were deemed sufficient to detect differences of one standard deviation between the two groups at $\mathrm{p}<0.05$ with $90 \%$ power [21]. The var-

Nifedipine, an Effective Tocolytic Agent with Fewer Side-Effects than Ritodrine ious data are expressed as mean values. Patients' variables (outcome of tocolysis and side-effects) are analysed by Student's t test and Fisher's exact test while haemodynamic changes are analysed by one-way analysis of variance (ANOVA), with significance at $p=$ 0.05 .

\section{Results}

During the study period, there were 2,673 preterm deliveries out of 29,376 total deliveries, giving an incidence of preterm delivery of $9.1 \%$. However, $862(32.2 \%)$ were from intervention with caesarean sections or induction of labour as a result of medical or obstetric complications. Genuine preterm labour and birth were therefore observed in 1,911 cases, which gave an incidence of $6.5 \%$. However, $1,285(67.2 \%)$ occurred between 34 and 36 weeks of gestation. Of the 626 below 34 weeks of gestation, $218(34.8 \%)$ had preterm premature rupture of membranes, 71 (11.4\%) breech presentation and $65(10.4 \%)$ lethal congenital anomalies and $164(26.1 \%)$ had cervical dilatation of $4 \mathrm{~cm}$ or more. Those who fulfilled eligibility criteria for the study were therefore 108 women $(5.7 \%$ of preterm deliveries and $0.4 \%$ of total deliveries). The demographic characteristics of the patients in the study are shown in table 1 . There were no significant differences in maternal age, parity, gestational age, cervical dilatation, and the status of preterm labour. Two patients in the ritodrine group changed their minds and refused therapy. The differential effects of ritodrine and nifedipine on maternal pulse are presented in figure 1 . There was a linear dosedependent increase of the pulse with ritodrine $(r=0.49, p<0.05)$. Ritodrine increased the maternal pulse more significantly than nifedipine at $1 \mathrm{~h}(\mathrm{p}<0.03), 2 \mathrm{~h}(\mathrm{p}<0.01)$ and at $3 \mathrm{~h}$ $(p<0.01)$ of initiation of tocolysis. With regard to the effects on blood pressure as shown in figure 2, the ritodrine group showed 
Table 1. Demographic characteristics of study patients

\begin{tabular}{lccl}
\hline & $\begin{array}{c}\text { Nifedipine } \\
(\mathrm{n}=30)\end{array}$ & $\begin{array}{c}\text { Ritodrine } \\
(\mathrm{n}=28)\end{array}$ & $\begin{array}{l}\mathrm{p} \\
\text { value }\end{array}$ \\
\hline Age, years & $26.2 \pm 5.5$ & $25.6 \pm 5.3$ & 0.93 \\
$<20$ & $4(13.3)$ & $6(21.4)$ & 0.11 \\
$20-29$ & $17(56.7)$ & $14(50.0)$ & 0.11 \\
$30-39$ & $8(26.7)$ & $7(25.0)$ & 0.85 \\
$\geq 40$ & $1(3.3)$ & $1(3.6)$ & 0.93 \\
\hline Previous history of preterm labour & \\
1 & $19(63.3)$ & $18(64.2)$ & 0.90 \\
2 & $7(23.3)$ & $7(25.0)$ & 0.90 \\
3 & $4(13.4)$ & $3(10.7)$ & 0.85 \\
\hline Parity (mean) & 2.4 & 2.9 & 0.19 \\
0 & $6(20.0)$ & $6(21.5)$ & 0.95 \\
$1-2$ & $10(33.3)$ & $10(35.7)$ & 0.93 \\
$3-4$ & $10(33.3)$ & $9(32.1)$ & 0.93 \\
$\geq 5$ & $4(13.4)$ & $3(10.7)$ & 0.85 \\
\hline Gestation on & \multicolumn{3}{c}{} \\
admission, weeks & $29.4 \pm 2.5$ & $29 \pm 2.3$ & 0.51 \\
$24-26$ & $4(13.3)$ & $4(14.3)$ & 0.85 \\
$27-29$ & $15(50.0)$ & $14(50.0)$ & 1.00 \\
$30-33$ & $11(36.7)$ & $10(35.7)$ & 0.95 \\
\hline Cervical dilation on admission & & \\
Os closed & $3(10.0)$ & $2(7.1)$ & 0.91 \\
$1-2$ cm & $21(70.0)$ & $21(75.0)$ & 1.01 \\
3 cm & $6(20.0)$ & $5(17.9)$ & 0.89 \\
\hline
\end{tabular}

Percentage is given in parentheses.

a trend towards a decrease in diastolic blood pressure from $1 \mathrm{~h}$ of infusion and from $2 \mathrm{~h}$ with systolic blood pressure, but the change was not statistically significant especially when compared to nifedipine. In table 2, other side-effects of the two tocolytics are compared. Flushing occurred almost equally in the two therapy groups. However, nausea, palpitations, and chest pain were significantly higher in the ritodrine group $(\mathrm{p}<0.01,0.01$, 0.01 ), respectively. The infusion was abandoned in 5 patients in the ritodrine group
Table 2. Comparison of other side-effects of nifedipine and ritodrine

\begin{tabular}{llll}
\hline & $\begin{array}{l}\text { Nifedipine } \\
(\mathrm{n}=30)\end{array}$ & $\begin{array}{l}\text { Ritodrine } \\
(\mathrm{n}=28)\end{array}$ & $\begin{array}{l}\mathrm{p} \\
\text { value }\end{array}$ \\
\hline Flushing & 6 & 5 & 0.94 \\
Headache & 0 & 1 & 0.21 \\
Hypotension & 1 & 2 & 0.11 \\
Nausea & 2 & 11 & 0.01 \\
Vomiting & 2 & 5 & 0.15 \\
Palpitations & 3 & 16 & 0.01 \\
Chest pain & 0 & 9 & 0.01 \\
\end{tabular}

Tocolysis was stopped because of severe hypotension, tachycardia, palpitations and chest pain in 5 women in the ritodrine group but none in the nifedipine group.

because of severe tachycardia with pulse rates more than 130 beats/min, palpitations and chest pain in 5 patients plus hypotension in 1 . None of the women in the nifedipine group had such side-effects. As shown in table 3, ritodrine had a quicker onset of inhibition of uterine contractions. At $40 \mathrm{~min}$ after initiation of tocolytic therapy, more women in the ritodrine group had cessation of uterine contractions than in the nifedipine group (74 versus $40 \%, \mathrm{p}<0.04)$. Conversely, more women in the nifedipine than ritodrine group had cessation of uterine contractions after more than 40 min (60 versus $26.1 \%$ ). Analysis of the interval between the initiation of tocolytic therapy and delivery showed that labour was delayed on the average for $40 \mathrm{~h}$ in the nifedipine group compared to $24 \mathrm{~h}$ in the ritodrine group $(\mathrm{p}<0.05)$. More women $(34.8 \%)$ in the ritodrine group compared to $13.3 \%$ in the nifedipine group delivered within $24 \mathrm{~h}$ of initiation of tocolysis $(\mathrm{p}<0.02)$. In $18(60 \%)$ in the nifedipine group compared to $9(39.1 \%)$ in the ritodrine group, uterine contractions were postponed for more than $48 \mathrm{~h}$. In 13 
Fig. 1. Differential effects of nifedipine and ritodrine on maternal pulse. Linear increase of pulse with ritodrine $(\mathrm{r}=0.49, \mathrm{p}<0.05)$ : ritodrine significantly increased the maternal pulse over nifedipine at $1 \mathrm{~h}(\mathrm{p}<0.034), 2 \mathrm{~h}(\mathrm{p}<0.01)$ and $3 \mathrm{~h}(\mathrm{p}<0.01)$.

Fig. 2. Effects of nifedipine and ritodrine on blood pressure. The ritodrine group showed a trend toward a decrease in blood pressure (statistically insignificant) especially compared to nifedipine.
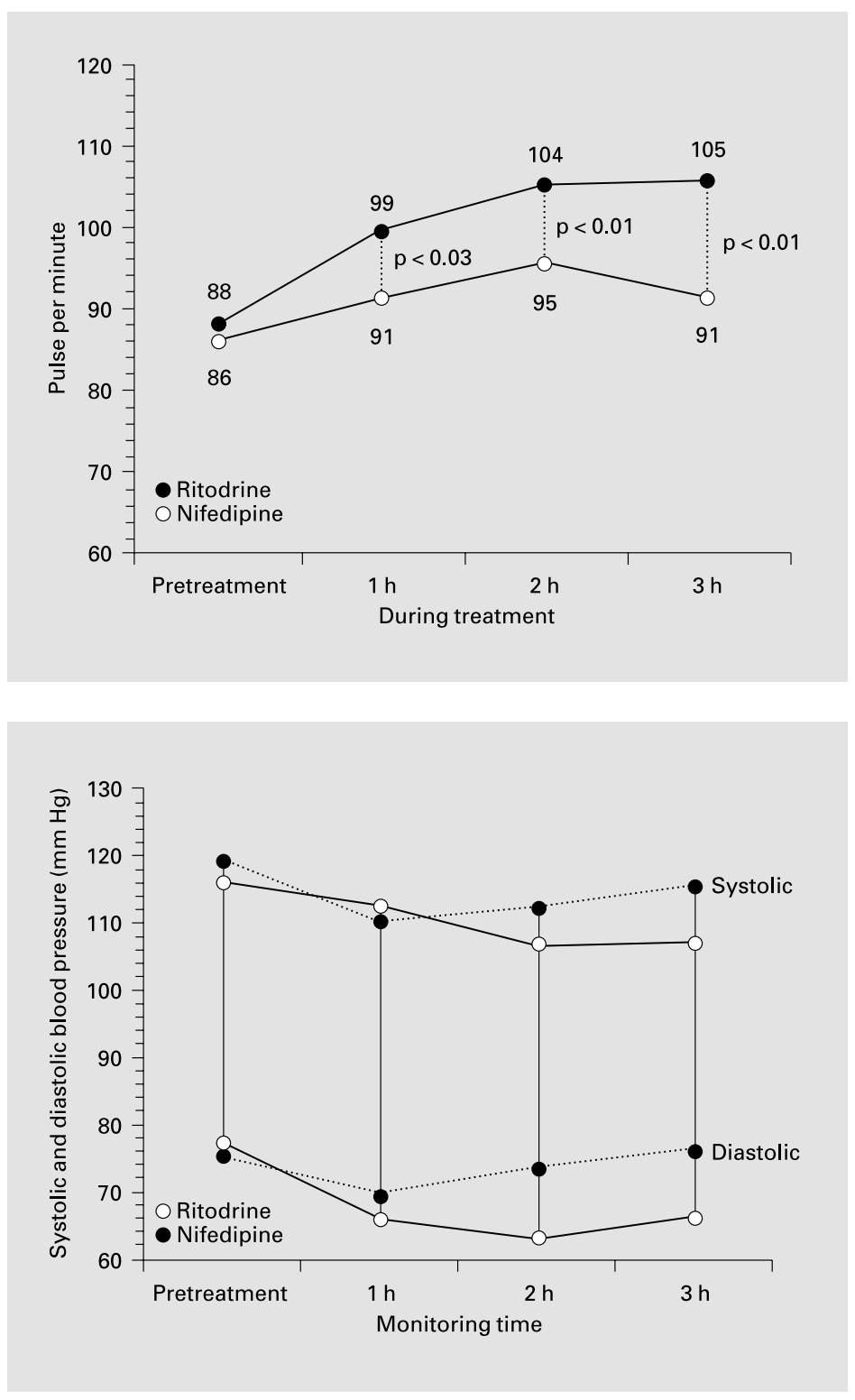

women $(43.3 \%)$ in the nifedipine group compared to $5(21.7 \%)$ in the ritodrine group, uterine contractions were postponed for over 7 days $(\mathrm{p}<0.05)$. More patients in the nifedipine group carried the pregnancy beyond 36 weeks than in the ritodrine group (33.3 versus

Nifedipine, an Effective Tocolytic Agent with Fewer Side-Effects than Ritodrine
$17.4 \%, \mathrm{p}<0.05)$. This shows that nifedipine was significantly more effective than ritodrine in aborting uterine contractions.

All the patients in both therapy groups had spontaneous vaginal delivery. Table 4 summarizes the obstetric and neonatal outcome.

Med Principles Pract 2000;9:164-173 169 
Table 3. Comparison of cessation of uterine contractions by nifedipine and ritodrine

\begin{tabular}{|c|c|c|c|}
\hline & $\begin{array}{l}\text { Nifedipine } \\
(\mathrm{n}=30)\end{array}$ & $\begin{array}{l}\text { Ritodrine } \\
(\mathrm{n}=23)\end{array}$ & $\begin{array}{l}\mathrm{p} \\
\text { value }\end{array}$ \\
\hline \multicolumn{4}{|c|}{$\begin{array}{l}\text { Interval between initiation of therapy and } \\
\text { cessation of uterine contractions }\end{array}$} \\
\hline $1-19 \min$ & $4(13.3)$ & $2(8.7)$ & 0.01 \\
\hline $20-40 \mathrm{~min}$ & $8(26.7)$ & $15(65.2)$ & 0.04 \\
\hline$\geq 41 \mathrm{~min}$ & $18(60.0)$ & $6(26.1)$ & 0.05 \\
\hline Treatment abandoned & $0(0)$ & $5(17.9)$ & 0.03 \\
\hline \multicolumn{4}{|c|}{ Initiation of therapy to delivery interval } \\
\hline Within $24 \mathrm{~h}$ & $4(13.3)$ & $8(34.8)$ & 0.05 \\
\hline $1-2$ days & $8(26.7)$ & $6(26.1)$ & 1.0 \\
\hline 3-7 days & $3(16.7)$ & $4(17.4)$ & 0.09 \\
\hline After 7 days & $13(43.3)$ & $7(21.7)$ & 0.05 \\
\hline$\geq 36$ weeks & $10(33.3)$ & $4(17.4)$ & 0.03 \\
\hline $\begin{array}{l}\text { Successful inhibition of } \\
\text { contractions }(\geq 48 \mathrm{~h})\end{array}$ & $18(60)$ & $9(39.1)$ & 0.05 \\
\hline
\end{tabular}

Percentage is given in parentheses.
Preterm labour was inhibited in more patients with nifedipine than ritodrine beyond 34 weeks of gestation (50 versus $21.8 \%, \mathrm{p}<$ 0.03 ) and up to 37 weeks and above (33.3 versus $13.1 \%, \mathrm{p}<0.01)$. There were no significant differences in the Apgar scores at 1 and $5 \mathrm{~min}$. The mean birth weight in the nifedipine group was higher than that of the ritodrine group, but the difference did not reach statistical significance. However, a breakdown of the birth weights revealed that more infants in the nifedipine group weighed $2.0 \mathrm{~kg}$ and above (60 versus $17.4 \%, \mathrm{p}<0.01$ ) and $2.5 \mathrm{~kg}$ and above $(26.7$ versus $13.0 \%, \mathrm{p}<$ 0.05 ). In both ritodrine and nifedipine treatment groups, 2 neonates developed mild and moderate RDS, respectively. There were no complications of intraventricular haemorrhage, bronchopulmonary dysplasia or ulcerative enterocolitis. The admission to SCBU was mainly because of low birth weight of the neonates. More infants in the ritodrine thera- py group $(17,73.9 \%)$ were admitted to SCBU compared to the nifedipine group $(14,46.7 \%$; $p<0.05)$. All the women went home with their babies without any perinatal mortality.

\section{Discussion}

The present study has shown that the incidence of spontaneous preterm labour of $6.5 \%$ is within the range of $5-10 \%$ in many institutions and geographical areas [1-3, 22]. Secondly, the study has highlighted the difficulty of selecting suitable patients with preterm labour for comparative evaluation of tocolytic agents. Out of 29,736 total deliveries, there were only 108 women that fulfilled the inclusion criteria for the study. The main finding of this study is that nifedipine is as effective as ritodrine for tocolysis. It significantly aborted premature uterine contractions for a much longer period than ritodrine. It also had fewer 
Table 4. Comparison of neonatal outcome

\begin{tabular}{llll}
\hline & $\begin{array}{l}\text { Nifedipine } \\
(\mathrm{n}=30)\end{array}$ & $\begin{array}{l}\text { Ritodrine } \\
(\mathrm{n}=23)\end{array}$ & $\begin{array}{l}\mathrm{p} \\
\text { value }\end{array}$ \\
\hline $\begin{array}{l}\text { Gestation at delivery } \\
\text { (mean } \pm \text { SD) }\end{array}$ & $30.2 \pm 2.6$ & $29.5 \pm 2.3$ & 0.12 \\
24-26 weeks & 4 & 5 & 0.15 \\
27-29 weeks & 6 & 7 & 0.20 \\
30-33 weeks & 5 & 6 & 0.20 \\
34-36 weeks & 5 & 2 & 0.05 \\
$\quad \leq 37$ weeks & 10 & 3 & 0.01 \\
\hline Apgar score at 1 min & $6.04 \pm 2.3$ & $6.12 \pm 1.7$ & 0.13 \\
Apgar score at 5 min & $6.9 \pm 2.6$ & $7.7 \pm 1.5$ & 0.11 \\
\hline Birth weight (mean \pm SD) & $2,202 \pm 790$ & $2,078 \pm 711$ & 0.61 \\
$\quad \leq 1.0 \mathrm{~kg}$ & 2 & 3 & 0.10 \\
1.0-1.49 kg & 6 & 8 & 0.90 \\
$1.5-1.99 \mathrm{~kg}$ & 4 & 5 & 0.90 \\
2.0-2.49 kg & 10 & 4 & 0.01 \\
$\quad 2.5$ & 8 & 3 & 0.05 \\
\hline RDS & & & \\
Mild & 2 & 2 & 1.00 \\
Moderate & 2 & 2 & 1.10 \\
Severe & 0 & 0 & - \\
\hline Intraventricular haemorrhage & 0 & 0 & - \\
\hline Perinatal mortality & 0 & 0 & \\
\hline
\end{tabular}

side-effects and an easier route of administration compared to ritodrine (oral versus intravenous). While ritodrine can postpone delivery for at least 1-2 days, this effect is thought to have limited impact on perinatal mortality and morbidity [20]. Although the $\beta$-sympathomimetic agent ritodrine hydrochloride is the only tocolytic agent approved for tocolysis by the US Food and Drug Administration, its manifold adverse effects of hyperglycaemia, hypokalaemia, hypotension, cardiac arrhythmia, myocardial ischaemia and tremor have restricted its wide use [10]. As demonstrated in the present study, the use of ritodrine is more significantly associated with palpitations, tremor, nausea and vomiting than with nifedipine. This is in accordance with the result of a meta-analysis by Oei et al. [23] on nifedipine versus ritodrine for suppression of preterm labour. In the five studies that reported on side-effects, nifedipine had 23/147 (16\%) and ritodrine 73/132 (45\%) patients with side-effects. Even an increased risk of cardiac ischaemia was reported with the use of ritodrine [24]. From the perspective of obsterical outcome in aborting premature uterine contractions and short-term neonatal outcomes, nifedipine should therefore be the drug of first choice. It is significantly more effective in delaying delivery beyond 36 weeks gestation.

In a randomized study on the efficacy and safety of nifedipine versus magnesium sulphate in the management of preterm labour 
[25], both tocolytic agents had similar efficacy. However, in the magnesium group, therapy was discontinued because of severe sideeffects, showing that nifedipine is probably safer than magnesium sulphate. In a more recent study, Larmon et al. [13] compared the efficacy and safety of oral nicardipine (closely related to nifedipine) in acute therapy for preterm labour with those of parenteral magnesium sulphate. There was a significant decrease in the time to uterine quiescence in the nicardipine group $(\mathrm{p}<0.01)$. Patients in the magnesium sulphate group were more likely to have recurrence of preterm labour necessitating further tocolytic attempts, and had more side-effects in the form of nausea and vomiting.

The mechanism of action of nifedipine is through vasodilatation by interfering with the excitation contraction coupling of vascular smooth muscle by hindering ionized calcium to enter through slow channels in the plasma membrane into the cell. Several investigators reported the effect of nifedipine on flow velocity waveform: they demonstrated that nifedipine treatment did not influence either fetal or uteroplacental circulation [18, 19, 26, 27]. It is generally considered to be safe for both mother and fetus and it reduces RDS and admission to NICU [23] as revealed by the present study. However, other workers have advocated that before nifedipine is introduced into clinical practice, the effectiveness should be assessed in a placebo-controlled trial. Secondly, it has been reported that maintenance tocolytic therapy with oral nifedipine does not significantly prolong pregnancy. Neither recent trials nor meta-analyses have shown any benefit of maintenance tocolytic therapy $[28,29]$.

Calcium channel antagonists are attractive alternative tocolytic agents because of their ease of administration, lack of need for blood level monitoring and limited adverse effect profile [30]. A similar calcium channel antagonist, nicardipine, has been shown in animal studies to inhibit myometrial contractility with a more potent inhibitor of muscle contraction than nifedipine; it can be given intravenously in nauseated patients who are unable to tolerate medication by mouth [13].

In conclusion, nifedipine is an effective tocolytic agent with fewer side-effects than ritodrine and it has the added advantage of ease of oral administration compared to intravenous ritodrine. While nifedipine was found to be a suitable alternative to ritodrine, the limited number of patients of this study necessitates further investigation with a larger number of participants to validate our findings. A multicentre study comparing nifedipine versus ritodrine in inhibiting preterm labour in a much larger number of patients is advocated.

\section{Acknowledgements}

The authors are grateful to all the doctors of the Maternity Hospital who allowed the inclusion of their patients to be recruited for this study, and the nursing staff in the labour wards and the lying-in wards. The co-operation of all the patients is greatly appreciated. 


\section{References}

1 Keirse MJ, Rush RW, Anderson $\mathrm{AB}$, Turnbull AC: Risk of preterm delivery in patients with previous preterm delivery and/or abortion. Br J Obstet Gynaecol 1978;85:8185.

2 Creasy RK: Preterm birth prevention: Where are we? Am J Obstet Gynecol 1993;168:1223-1230.

3 Beukens P, Alexander S, Boutsen M, Blondel B, Kaminski M, Reid M: Randomised controlled trial of routine cervical examination in pregnancy. Lancet 1994;344:841-844.

4 Ali KZ, Ali ME, Khalid ME: High altitude and spontaneous preterm birth. Int J Gynaecol Obstet 1996; 54:11-15.

5 Penn ZJ, Steer PJ: Preterm labour in recent advances in obstetrics and gynaecology; in Bonnar (ed): No 20 . London. Churchill Livingstone, 1998, pp 97-119.

6 American College of Obstetricians and Gynecologists: Preterm Labor. Techn Bull 206. Washington, American College of Obstetricians and Gynaecologists, 1995:1-13.

7 Papiernik E: Epidemiology of preterm births and its change over time (1971-1986). Eur J Obstet Gynecol Reprod Biol 1989;33:7-9.

8 Tucker JM, Goldenberg RL, Davis RO, Copper RL, Winkler CL, Hauth $\mathrm{JC}$ : Etiologies of preterm birth in an indigent population: Is prevention a logical expectation? Obstet Gynecol 1991;77:343-347.

9 Lamont RF, Dunlop PD, Elder MG: Spontaneous preterm labour and delivery at 34 weeks' gestation. BMJ 1983;287:502.

10 Benedetti TJ: Maternal complications of parenteral beta-sympathomimetic therapy for premature labour. Am J Obstet Gymecol 1983 145:1-6.

Nifedipine, an Effective Tocolytic Agent with Fewer Side-Effects than Ritodrine
11 Morales WJ, Madhaw H: Efficacy and safety of indomethacin com pared with magnesium sulphate in the management of preterm labor: A randomized study. Am J Obstet Gynecol 1993;169:97-102.

12 Hollander DI, Nagey DA, Pupkin MJ: Magnesium sulfate and ritodrine hydrochloride: A randomized comparison. Am J Obstet Gynecol 1987;156:631-637.

13 Larmon JE, Ross BS, May WL, Dickerson GA, Fischer RG, Morrison JC: Oral nicardipine versus intravenous magnesium sulfate for the treatment of preterm labor. Am J Obstet Gynecol 1999;181:14321437.

14 Ulmsten U, Andersson KE, Wingerup L: Treatment of premature labor with the calcium antagonist nifedipine. Arch Gynecol 1980;229:1-5.

15 Read MD, Wellby DE: The use of a calcium antagonist (nifedipine) to suppress preterm labour. Br J Obstet Gynaecol 1986;93:933-937.

16 Ferguson JE 2nd, Schultz T, Pershe $\mathrm{R}$, Stevenson DK, Blaschke T: Nifedipine pharmacokinetics during preterm labor tocolysis. Am J Obstet Gynecol 1989;161:1485-1490.

17 Ferguson JE 2nd, Dyson DC, Schutz T, Stevenson DK: A comparison of tocolysis with nifedipine or ritodrine: Analysis of efficacy and maternal, fetal and neonatal outcome. Am J Obstet Gynecol 1990;163: 105-111.

18 Meyer WR, Randall HW, Graves WL: Nifedipine versus ritodrine for suppressing preterm labour. J Reprod Med 1990;35:649-653.

19 Bacero LA, Leikin E, Kirshenbaum $\mathrm{N}$, Tejani N: Comparison of nifedipine and ritodrine for the treatmen of preterm labour. Am J Perinatol 1991;8:365-369.

20 Kupferminc M, Lessing JB, Yaron Y, Peyser MR: Nifedipine versus ritodrine for suppression of preterm labour. Br J Obstet Gynaecol 1993; 100:1090-1094.
21 Altman DG: Practical Statistics for Medical Research. London, Chapman \& Hall, 1991, pp 455-560.

22 Lumley J: The epidemiology of preterm birth. Baillière's Clin Obstet Gynaecol 1993;7:477-498.

23 Oei SG, Mol BW, deKleine MJ, Brolmann HA: Nifedipine versus ritodrine for suppression of preterm labor: A meta-analysis. Acta Obstet Gynecol Scand 1999;78:783-788.

24 Lamont RF: The contemporary use of beta-agonists. Br J Obstet Gynaecol 1993;100:890-892.

25 Glock JL, Morales WJ: Efficacy and safety of nifedipine versus magnesium sulphate in the management of preterm labor: A randomised study. Am J Obstet Gynecol 1993;169: 960-964.

26 Lindow SW, Davies N, Davey DA, Smith JA: The effect of sublingual nifedipine on uteroplacental bloodflow in hypertensive pregnancy. Br J Obstet Gynaecol 1988;95:12761281.

27 Pirhonen JP, Erkkola RU, Ekblad UU, Myman L: Single dose of nifedipine in normotensive pregnancy: Nifedipine concentration, hemodynamic responses and uterine and fetal flow velocity wave forms. Obstet Gynecol 1990;76:807-811.

28 Sanchez-Ramos, Wears RL, Gaudier FL, Delke I, Kaunitz AM: Efficacy of maintenance therapy after acute tocolysis: A meta-analysis (abstract). Am J Obstet Gynecol 1999; 181:484-490.

29 Macones GA, Berlin M, Berlin JA: Efficacy of oral beta-agonist maintenance therapy in preterm labor: A meta-analysis. Obstet Gynecol 1995;85:313-317.

30 Lockword CJ: Calcium-channel blockers in the management of preterm labour. Lancet 1997;350: 1339-1340. 